\title{
Effect of the backfat thickness of sows in late pregnancy on the composition of colostrum and milk
}

\author{
KAROLINA BEYGA and ANNA REKIEL
}

Department of Animal Breeding and Husbandry, Faculty of Animal Science, Warsaw University of Life Sciences, Poland

\begin{abstract}
The aim of the work was to determine the effect of the condition of the sows in high pregnancy, being expressed by fat reserves and body weight, and of lactation period on chemical composition and energy content as well as physical and cytological parameters of colostrum and milk of the sows. The studies were conducted with 100 sows (PLW $\times P L)$, classified into the groups according to backfat thickness: I - $\left(P_{2}+P_{4}\right) / 2>20 \mathrm{~mm}$ and II $-\left(P_{2}+P_{4}\right) / 2 \leq 20 \mathrm{~mm}$. The experiment was performed since 104th day of pregnancy till weaning of piglets after 21-day lactation. Fatness (points $P_{2}$ and $P_{4}$ ) and their changes during the periods: high pregnancy - parturition - weaning as well as physical and cytological parameters and colostrum and milk composition were examined.

Domination of fatness in highly pregnant sows from group I vs. II was maintained during parturition and weaning $(P \leq 0.001)$. Any effect of the sow condition on colostrum and milk quality was not found. In case of lower fat reserves in sows (group II vs. I) only lower fat content in colostrum and its lower energy content (by 16.3\% and 4.9\%, respectively), was found. For the majority of parameters no significant differences between the two groups were found. Only the bodyweight at weaning in group II, despite smaller number of piglets in the litter, was found to be significantly lower.
\end{abstract}

Keywords: sows, backfat thickness, colostrum, milk

\section{Zusammenfassung}

\section{Einfluss der Rückenspeckdicke von hochtragenden Sauen auf die Zusammensetzung von Biestmilch und Milch}

Ziel der Untersuchung war die Prüfung des Einflusses der Rückenspeckdicke hochtragender Sauen auf die Zusammensetzung ihrer Biestmilch und Milch, wobei neben der chemischen Zusammensetzung und des Energiegehaltes physiologische und zytologische Merkmale erfasst wurden. Genutzt wurden 100 Kreuzungssauen aus der Kombination Polnische Große Weiße $\times$ Polnische Landrasse die auf Grund ihrer durchschnittlichen Rückenspeckdicke von zwei Messpunkten am 104. Tag zwei Gruppen zugeordnet wurden: $I=\left(P_{2}+P_{4}\right) / 2>20 \mathrm{~mm}$ und $I I=\left(P_{2}+P_{4}\right) / 2 \leq 20 \mathrm{~mm}$. Weitere Speckdickenmessungen sowie die Bestimmung der Milchzusammensetzung erfolgten nach der Abferkelung und beim Absetzen der Ferkel am 21. Tag. Der höhere Rückenfettgehalt in der Gruppe I gegenüber II blieb bis zum Absetzzeitpunkt erhalten, ein Einfluss auf die Zusammensetzung der Biestmilch 
und Milch konnte nicht nachgewiesen werden. In der Gruppe II fand sich ein tendenziell niedrigerer Fettgehalt und energetischer Wert in der Biestmilch und Milch. In der Mehrzahl aller untersuchten Inhaltstoffe fanden sich keine signifikanten unterschiede zwischen den Gruppen. Lediglich die Absetzgewichte der Ferkel in der Gruppe II lagen trotz einer geringeren Ferkelzahl im Wurf signifikant niedriger.

Schlüsselwörter: Sau, Rückenspeckdicke, Biestmilch, Milch

\section{Introduction}

Milk yield and quality traits of colostrum and milk (i.e. physical, cytological and chemical properties) are dependent on genotype, feeding, lactation stage, health state and number of fed young animals (COFFEY et al. 1982, CSAPÓ et al. 2001, MIGDAŁ et al. 2003, REKIEL et al. 2006). There is a lack of the studies, determining the quality of the discussed feed, depending on the accumulated fat and protein reserves in sow body. Synthesis of the components for milk production occurs as early as few weeks before parturition (WHITELEY et al. 1990 and DODD et al. 1994 cit. after REKIEL 2003, McNAMARA 2008a, 2008b). During the period preceding parturition, i.e. in high pregnancy, some sows lose part of early accumulated reserves what may be connected with somatic development and/or their utilization in growth and development of fetus as well as with the synthesis of components of colostrum and milk (REKIEL 2000, http://ohioline.osu.edu/b869/b869_42.html). The scale of requirements and priorities may be differentiated and dependent on degree of somatic maturity of female, its age, body weight, the possessed reserves and also, on the number of fetuses and born piglets, coverage of nutritional requirements, or also, environmental conditions (KÄMMERER et al. 1998, WÄHNER et al. 2001, CECHOVA and TVRDON 2006).

The aim of the studies was to determine the effect of the highly pregnant sows' condition, being expressed in fat reserves and lactation stage on the selected physical, cytological and chemical traits of colostrum and milk of the sows coming from crossbreds of maternal breeds.

\section{Material and methods}

The studies included two groups of sows - crossbreds of breeds: Polish Large White $\times$ Polish Landrace (each group consisting of 50 animals) and their progeny; participation of multiparous and primiparous sows amounted to 70 and $30 \%$, respectively. The animals were kept in the individual boxes and fed the same full-ration mixture $(2270 \mathrm{kcal} / \mathrm{kg}, 17 \%$ protein, $1 \%$ lysine) according to the principles, specified in Polish Swine Nutrition Requirements (ANONYMOUS 1993); during pregnancy, the feed was administrated twice a day and during lactation 3 times per day. Its intake during lactation was similar in groups I and II and it amounted, in total, to $100.7 \mathrm{~kg}$ (group I) and $105.7 \mathrm{~kg}$ (group II) during 3-week period. Since the 5th day of life, the piglets were additionally fed with the prestarter mixture. Classification of the sows into groups was performed on the 104th day of gestation ( $\pm 2-3$ days) on the ground of arithmetic mean of backfat thickness $\left(P_{2}+P_{4}\right) / 2$, calculated from ultrasonographic measurements of fatness in two points, i.e. $P_{2}$ 
and $\mathrm{P}_{4}$ ( 3 and $8 \mathrm{~cm}$ from back line on the level of last thoracic vertebra; group $1>20 \mathrm{~mm}$ and group $I I \leq 20 \mathrm{~mm}$. The condition of sows, expressed by mean fat reserve was determined on the 104th day of gestation, at parturition and at weaning (21 $11-2$ days). According to the assumptions, the mean fatness of the sows in three examined dates differed between the groups $(P \leq 0.001)$. It was as follows: group I - 26.19, 24.91 and $21.60 \mathrm{~mm}$ and group II $-15.24,16.26$ and $12.29 \mathrm{~mm}$. Basic analyses of feeds for sows and piglets were carried out (AOAC 1990).

Basic parameters of reproduction and rearing of piglets were controlled. Functional changes of mammary gland on the ground of the selected physical, cytological and chemical parameters of colostrum and milk were evaluated.

The samples of colostrum and milk $(50 \mathrm{ml})$ were collected from the same 34 sows (17 animals from each group) during parturition and on the day of weaning (after injection of oxytocin $-1 \mathrm{ml} / 100 \mathrm{~kg}$ of body weight [BW]) and were preserved (Mlekostat CC). Active acidity $(\mathrm{pH})$ of colostrum and milk was determined using $\mathrm{pH}$-meter $\mathrm{pH} 211$ of Hanna Instruments company and somatic cell count (SCC) - by Somacount 150 of Bentley company.

Energy level in milk was calculated, adopting the following mean values for the particular basic components: fat $-9.5 \mathrm{kcal}$, protein $-5.7 \mathrm{kcal}$ and lactose $-4.2 \mathrm{kcal}$ (RUSZCZYC 1985). In the samples of colostrum and protein, total chemical composition (i.e. fat, protein, lactose and dry matter content) was determined by spectrophotometric method in infrared using Milkoscan FT 120 of Foss Electric company). Fat of colostrum and milk was extracted by Röse-Gottlieb method (AOAC 1990). Analyses were performed in two repetitions; the content of the particular acids was the mean from two measurements. The particular standards and Lipid mix C4-C24 of the determined acids came from Supelco company. In the samples of colostrum and milk, the content of calcium (Ca), magnesium $(\mathrm{Mg}$ ) and phosphorus $(\mathrm{P})$ was determined by the method of atomic emission spectrometry with induced plasma (BOSS and FREDEEN 1989) and that of sodium $(\mathrm{Na})$ and potassium $(\mathrm{K})$ was determined by the method of flame atomic absorption spectrometry FAAS (BRYŁKA 1995). The samples were mineralized by microwaves. Multipoint calibration was performed using the solutions of multi-element standards of Merck company (no 1.11355). The results were statistically analyzed, using one-factor variance analysis with an application of the smallest square method (SPSS 12.0 PL for Windows, 2003). Numerical values of somatic cell count were subjected to logarithmic transformation. The smallest square means together with their standard errors were given in the tables.

\section{Results}

The selected parameters of reproduction and rearing of piglets, depending on the condition of the sows have been given in table 1. The sows from group I vs. II were characterized by a higher (by 11.1 animals) number of live born piglets $(P \leq 0.05)$. Deaths in group I and II amounted to $9.1 \%$ and $3.6 \%$, respectively. The mean body weight of piglets at weaning between groups I and II differed by $0.37 \mathrm{~kg}$ in favour of group I $(P \leq 0.05)$. Any statistically significant differences in the selected physical and cytological parameters and in chemical composition of colostrum and milk of the sows between the groups I and II were not found (Table 2). 
Table 1

Effect of sows' backfat thickness on the selected traits of piglets' reproduction and rearing Einfluss der Rückenspeckdicke auf Wurfgröße und Ferkelgewichte

\begin{tabular}{lcccc}
\hline Traits & Group I & Group II & SE & Significance level \\
\hline Number of live born piglets, heads & 10.78 & 9.67 & 0.236 & ${ }^{*}$ \\
Number of weaned piglets, heads & 9.82 & 9.46 & 0.152 & $\mathrm{~ns}$ \\
Mean body weight of piglet at birth, kg & 1.63 & 1.68 & 0.040 & $\mathrm{~ns}$ \\
Mean body weight of piglet at weaning, kg & 6.02 & 5.65 & 0.076 & $*$ \\
\hline
\end{tabular}

Group I - $\left(\mathrm{P}_{2}+\mathrm{P}_{4}\right) / 2>20 \mathrm{~mm}$, Group II $-\left(\mathrm{P}_{2}+\mathrm{P}_{4}\right) / 2 \leq 20 \mathrm{~mm}$, SE standard error, ${ }^{*}$ Means differ statistically significantly at $P \leq 0.05$, ns not significant.

Table 2

Chemical composition and the selected physical and cytological parameters of colostrum and milk Chemische Zusammensetzung und ausgewählte physikalische und zytologische Merkmale von Biestmilch und Sauenmilch

\begin{tabular}{|c|c|c|c|c|c|c|c|c|c|c|c|c|}
\hline \multirow{2}{*}{ Traits } & \multicolumn{4}{|c|}{ Colostrum } & \multicolumn{4}{|c|}{ Milk } & \multirow{2}{*}{ Colostrum } & \multirow{2}{*}{ Milk } & \multirow{2}{*}{ SE } & \multirow{2}{*}{ SL } \\
\hline & Group I & Group II & SE & SL & Group I & Group II & SE & $\mathrm{SL}$ & & & & \\
\hline Energy, kJ & 6800 & 6465 & 176.73 & ns & 4493 & 4659 & 73.35 & ns & 6627 & 4576 & 96.64 & $* * *$ \\
\hline $\mathrm{DM}, \%$ & 26.6 & 25.7 & 0.572 & ns & 18.0 & 18.4 & 0.183 & ns & 26.1 & 18.2 & 0.303 & $* * *$ \\
\hline$C P, \%$ & 15.9 & 16.1 & 0.445 & ns & 4.0 & 3.9 & 0.073 & ns & 16.0 & 3.9 & 0.225 & $* * *$ \\
\hline Lactose, \% & 3.6 & 3.6 & 0.077 & ns & 6.2 & 6.1 & 0.061 & ns & 3.6 & 6.1 & 0.049 & $* * *$ \\
\hline Fat, \% & 5.9 & 4.9 & 0.332 & ns & 6.2 & 6.7 & 0.203 & ns & 5.4 & 6.4 & 0.199 & $* * *$ \\
\hline $\mathrm{pH}$ & 6.12 & 6.17 & 0.033 & ns & 6.87 & 6.87 & 0.019 & ns & 6.3 & 6.9 & 0.019 & $* * *$ \\
\hline$S C C \times 1000$ & 2276 & 1471 & 395.24 & ns & 3277 & 3208 & 655.73 & ns & 1874 & 3242 & 899 & ns \\
\hline LN SCC & 7.48 & 6.98 & 0.255 & ns & 7.65 & 7.35 & 0.203 & ns & 7.22 & 7.50 & 0.163 & ns \\
\hline
\end{tabular}

SE standard error, SL significance level, Group I - $\left(\mathrm{P}_{2}+\mathrm{P}_{4}\right) / 2>20 \mathrm{~mm}$; Group II $-\left(\mathrm{P}_{2}+\mathrm{P}_{4}\right) / 2 \leq 20 \mathrm{~mm}$, DM dry matter, CP crude protein, ${ }^{* * *}$ Means differ statistically significantly at $P \leq 0.001$, ns not significant.

Colostrum of the sows from group I as compared to group II was characterized by higher energy content (by $335.4 \mathrm{~kJ}$ ) and by higher dry matter and fat content (by 0.9 and 1.0 percentage points, respectively). The milk from the sows from group I vs. group II was characterized by lower (by $166.25 \mathrm{~kJ}$ ) energy content. Dry matter was found lower by 0.4 percentage point and fat - lower by 0.5 percentage point. When we compare the changes between the basic composition of colostrum and milk, we may state that in a final stage of lactation as compared to the initial stage, the content of dry matter was decreased in groups II and II by ca. $8 \%$, in average, and that one of crude protein in both groups - more than four times. The content of lactose was almost twice increased and that one of fat in the sows from group I was increased by $0.3 \%$ whereas in group II, it increased by 1.7 percentage point. Acidity was increased by 0.7 in both groups. Somatic cell count in milk as compared to colostrum from the sows of group I increased by ca. $1 \mathrm{mln}$ and in group II - by more than $1.7 \mathrm{mln}$.

Energy content, basic chemical composition and $\mathrm{pH}$ of colostrum and milk differed statistically highly significantly $(P \leq 0.01)$ (Table 2$)$.

Differences in the content of the selected mineral components in colostrum and milk of the sows between group I and II were not statistically confirmed (Table 3).

The content of calcium in milk as compared to colostrum was increased by more than 3.5 times, that one of magnesium - by ca $35 \%$, of phosphorus by $40-45 \%$ while the content of sodium was decreased by $55 \%$ and that of potassium by $20-25 \%$. Highly significant differences between colostrum and milk were found for the content of macroelements $(P \leq 0.01)$ (Table 3$)$. 
Table 3

The selected mineral components of colostrum and milk of the sows $\left(\mathrm{mg} \cdot \mathrm{g}^{-1}\right)$

Ausgewählte Mineralien von Biestmilch und Sauenmilch

\begin{tabular}{|c|c|c|c|c|c|c|c|c|c|c|c|c|}
\hline \multirow{2}{*}{ Macroelements } & \multicolumn{4}{|c|}{ Colostrum } & \multicolumn{4}{|c|}{ Milk } & \multirow{2}{*}{ Colostrum } & \multirow{2}{*}{ Milk } & \multirow{2}{*}{ SE } & \multirow{2}{*}{ SL } \\
\hline & Group I & Group II & SE & $S L$ & Group I & Group II & SE & SL & & & & \\
\hline Calcium & 548.8 & 518.5 & 47.091 & ns & 2039.1 & 1849.1 & 73.453 & ns & 533.6 & 1944.1 & 43.850 & $* * *$ \\
\hline Magnesium & 85.1 & 75.9 & 5.383 & ns & 116.5 & 99.8 & 5.275 & ns & 80.5 & 108.2 & 3.822 & $* * *$ \\
\hline Phosphorus & 936.3 & 942.4 & 55.082 & ns & 1380.9 & 1301.4 & 35.403 & ns & 939.3 & 1341.1 & 32.245 & $* * *$ \\
\hline Potassium & 1157.7 & 1272.3 & 63.088 & ns & 919.1 & 957.9 & 26.438 & ns & 1215.0 & 938.5 & 34.023 & $* * *$ \\
\hline Sodium & 888.0 & 826.6 & 64.672 & ns & 378.1 & 375.6 & 16.985 & ns & 857.3 & 376.9 & 32.799 & $* * *$ \\
\hline
\end{tabular}

Group I - $\left(\mathrm{P}_{2}+\mathrm{P}_{4}\right) / 2>20 \mathrm{~mm}$, Group II $-\left(\mathrm{P}_{2}+\mathrm{P}_{4}\right) / 2 \leq 20 \mathrm{~mm}$, SE standard error, SL significance level, ***Means differ statistically significantly at $P \leq 0.001$, ns not significant.

Any statistically significant differences in profile of fatty acids between groups I and II were not found (Table 4).

Table 4

Profile of the selected fatty acids in fat of colostrum and milk of sows, \%

Ausgewählte Fettsäurenanteile im Fett von Biestmilch und Sauenmilch

\begin{tabular}{|c|c|c|c|c|c|c|c|c|c|c|c|c|}
\hline \multirow{2}{*}{ Acids } & \multicolumn{4}{|c|}{ Colostrum } & \multicolumn{4}{|c|}{ Milk } & \multirow{2}{*}{ Colostrum } & \multirow{2}{*}{ Milk } & \multirow{2}{*}{ SE } & \multirow{2}{*}{$S L$} \\
\hline & Group I & Group II & SE & SL & Group I & Group II & SE & SL & & & & \\
\hline $\begin{array}{l}\text { Myristic, } \\
\text { C } 14: 0\end{array}$ & 2.07 & 1.99 & 0.078 & ns & 3.57 & 3.53 & 0.101 & ns & 2.03 & 3.56 & 0.064 & $* * *$ \\
\hline $\begin{array}{l}\text { Palmitic, } \\
\text { C } 16: 0\end{array}$ & 24.97 & 25.87 & 0.386 & ns & 34.01 & 34.05 & 0.718 & ns & 25.44 & 34.05 & 0.432 & $* * *$ \\
\hline $\begin{array}{l}\text { Palmitooleic } \\
\text { C } 16: 1\end{array}$ & 3.15 & 3.04 & 0.083 & ns & 9.75 & 9.75 & 0.472 & ns & 3.09 & 9.75 & 0.264 & $* * *$ \\
\hline $\begin{array}{l}\text { Stearic, } \\
\text { C } 18: 0\end{array}$ & 5.36 & 5.83 & 0.140 & ns & 4.64 & 4.74 & 0.156 & ns & 5.61 & 4.69 & 0.107 & $* * *$ \\
\hline $\begin{array}{l}\text { Oleic, } \\
\text { C 18:1 }\end{array}$ & 32.14 & 32.04 & 0.405 & ns & 30.41 & 30.21 & 0.943 & ns & 32.09 & 30.32 & 0.549 & ns \\
\hline $\begin{array}{l}\text { Linoleic, } \\
\text { C } 18: 2\end{array}$ & 16.16 & 15.71 & 0.304 & ns & 8.45 & 8.41 & 0.133 & ns & 15.93 & 8.42 & 0.153 & $* * *$ \\
\hline $\begin{array}{l}\text { CLA, } \\
\text { C } 18: 2 \text { cis } 9 \text { trans } 11\end{array}$ & 0.35 & 0.35 & 0.013 & ns & 0.39 & 0.38 & 0.028 & ns & 0.35 & 0.39 & 0.017 & ns \\
\hline $\begin{array}{l}\text { Linolenic, } \\
\text { C 18:3 }\end{array}$ & 1.43 & 1.33 & 0.030 & ns & 0.73 & 0.70 & 0.017 & ns & 1.38 & 0.72 & 0.018 & $* * *$ \\
\hline $\begin{array}{l}\text { Arachidonic, } \\
\text { C 20:4 }\end{array}$ & 1.08 & 1.10 & 0.022 & ns & 0.44 & 0.48 & 0.012 & ns & 1.09 & 0.46 & 0.012 & $* * *$ \\
\hline
\end{tabular}

Group I - $\left(\mathrm{P}_{2}+\mathrm{P}_{4}\right) / 2>20 \mathrm{~mm}$, Group II $-\left(\mathrm{P}_{2}+\mathrm{P}_{4}\right) / 2 \leq 20 \mathrm{~mm}$, SE standard error, SL significance level, ***Means differ statistically significantly at $P \leq 0.001$, ns not significant.

The participation of determined fatty acids in fatty acid profile in colostrum fat, in groups I and II was as follows: oleic acid>palmitic acid>linoleic acid >stearic acid.

The participation of arachidonic acid and conjugated linoleic acid (CLA) was the lowest one. The participation of the selected acids in fatty acid profile in milk fat was changed as compared to colostrum and it was as follows: palmitic acid>oleic acid>palmitoleic acid>linolenic acid. Similarly as in case of colostrum fat, the participation of arachidonic acid and CLA was the lowest in milk fat.

When comparing colostrum and milk collected from the sows from group I as II (Table 4), it may be stated that the participation of palmitic acid was increased by 10 percentage points, that of oleic acid was decreased by 2 percentage points, of palmitoleic was increased by more than 3 times, of linoleic acid was decreased by twice, of stearic acid 
was decreased by $1 \%$, of myristic acid was increased by 1.5 percentage point, of linolenic acid was decreased twice and that of CLA remained on the same level.

Profile of the selected fatty acids in fat of colostrum and milk of the sows differed highly significantly $(P \leq 0.01)$, excluding CLA the participation of which was the lowest one in the profile; the participation of oleic acid was the highest one in the profile (Table 4).

\section{Discussion}

Body weight of 3-week old piglets from groups I and II at weaning indicates the sufficient supply of energy and nutrients taken together with mother food and with solid feed (REKIEL 2002). Milk production is linearly correlated with the size of litter and intensity of sucking increases daily milk production even by $100 \%$ due to hypertrophy of mammary gland tissue (REVELL et al. 1998, AULDIST et al. 2000, REKIEL 2000, 2006). Immunological proteins and nutrients ensure high growth and development of piglets (KORHONEN et al. 2000) what is confirmed by high correlation between the body weight of the litter on the 21st day of life and the quantity of the milk, produced by the sow ( $r=0.88$ to 0.99 ) (WALKIEWICZ 1976, cit. after REKIEL 2000).

Mammary gland of the sow develops intensively during the last stage of gestation and in lactation (WHITTEMORE 1993). Secretion of colostrum may occur at parturition, on one or two days before or after delivery of progeny (CSAPÓ et al. 1996). Substrates used for production of mother food come not only from feed components but also from body reserves. The optimal condition of the pregnant sow and the level of its nutrition in high pregnancy and during feeding the progeny are, therefore, important element of lactation as at this time, the synthesis of colostrum and milk components takes place (WHITELY et al. 1990 and DOOD et al. 1994, cit. after REKIEL 2003). REVELL et al. (1998) demonstrated that over-fattened sows produced less milk by $15 \%$ as compared to lean animals and differences become more evident at the beginning of lactation. As it was reported by YOUNG et al. (2004), the number of secreting alveolar cells in fattened sows is decreased what causes lowering of colostrum and milk production. Production of milk and its energetic value at the beginning of lactation is higher if the nutrition employed during management period enabled to accumulate the appropriate reserves in female's body. It is indicated by body weight and thickness of back fat (COZLER et al. 1998). As it was reported by MULLAN and WILLIAMS (1989) and TILTON et al. (1999), in case of limited feeding during lactation, the sows are able to maintain a high level of milk production via mobilization of body reserves. Lack of significant differences in quality of colostrum and milk of the sows from groups I and II, with maintaining the condition of the sows, as mentioned in the methodology, shows that the feed - which was under control during lactation period - covered own requirements and was the main source of nutrients for synthesis of colostrum and milk components.

Acidity of colostrum and milk in own studies was found on a level typical of the animal species and lactation stage (COFFEY et al. 1982, MIGDAŁ et al. 2000, REKIEL 2002). During lactation, increase of $\mathrm{pH}$ of colostrum and milk was observed: from 6.09-6.30 to 6.70-6.95. The changes in $\mathrm{pH}$ are closely correlated with the changes in chemical composition; these changes are dependent, inter alias, on health state of the sow and its mammary gland (REKIEL 2006). Under the situation of inflammatory state, $\mathrm{pH}$ of milk is 
changed. It adopts values above 7.0 (PERSSON et al. 1983, cit. after REKIEL 2002). It also contains the increased number of somatic cells (SCC $\left.>2 \cdot 10^{6} / 1 \mathrm{ml}\right)$ (ŻYCZKO et al. 1984, cit. after REKIEL 2002). In own studies, the sows from group II vs. I had more favourable, lower somatic cell count (by 35.4\%) in colostrum; their level was found within the frames of standard adopted for the species. The level of SCC in milk of the sows from group I and II exceeded standard. In healthy sows, as compared to the females with sub-clinical form of mastitis, a negative correlation between the somatic cell count and percentage of blood lymphocytes was recorded (SCHOLLENBERGER and DEGÓRSKI 1990, cit. after REKIEL 2002). In the sows being under observation, sub-clinical states of mastitis were found but they were treated. A stable and low level of sodium in the sow milk and rectal temperature, being found within the standard and showing declining tendency during the successive days after parturition $\left(39.6-39.1^{\circ} \mathrm{C}\right)$ indicate also a satisfactory health state of mammary gland.

Energy level in colostrum and its fat content was lower for the sows from group II vs. I (by $335.4 \mathrm{~kJ}$ and $0.96 \%$ ). These relationships were confirmed by REVELL et al. (1998) who obtained higher (by $21 \%$ ) fat content in the milk at early stage of lactation of the sows with a thicker layer of backfat as compared to the females with thinner layer of backfat. VALROS et al. (2004) express the opinion that during the suckling period, there is a relationship between the basic concentration of oxytocin in the sows body and mobilization of body's reserves. The higher is basic level of oxytocin, the greater the mobilization of body reserves is. It facilitates and increases milk production and has a favorable influence on the growth rate of the piglets. When administrating oxytocin during parturition to all the sows (own studies), its effect on mobilization of body reserves and composition of colostrum and milk, was not determined. Energy level in colostrum and milk of the examined sows was comparable to the results of MIGDAŁ et al. (2000). The results of own studies and those found in literature (WALKIEWICZ et al. 1994, REVELL et al. 1998) indicate that the changes in protein: energy ratio during lactation may be dependent, at its early stage, on »body composition « of the sow. According to the authors, the mentioned ratio indicates also a greater possibility of utilizing amino acids from lean mother body (more meat than fat) for production of milk constituents. Owing to this, the energy of colostrum and milk of the sows may be additionally affected by nutrition methods, employing, inter alias, fat addition to the feed. Lack of significant differences in fat content and energy leveling milk between group I and II, as being found in own studies, corresponds with the results of the cited authors.

Induction of parturitions means that in a part of the sows, the delivery of progeny occurs prematurely i.e. on the 110th-112th day of gestation (JACKSON et al. 1995). It was demonstrated that the mean fat content in milk of the sows who gave the birth to its progeny before the determined date was statistically significantly lower than in case of the sows which farrowed at time. The application of feed with the addition of fat in the nutrition of such sows maintains the level of lipids in colostrum on a high, stable level and the increase of energy content in milk has a favourable effect on survival and growth rate of the piglets. The energy content in milk in groups I and II was similar what resulted from the uniform nutrition of sows during lactation. In case of higher index of deaths of the piglets in group I vs. II and comparable population of weaned litters, the piglets form 
group I as compared to group II were heavier $(P \leq 0.05)$. The discussed result could be affected by better milk yield of the sows from group I in comparison with group II as a consequence of significantly higher $(P \leq 0.05)$ number of live born piglets and greater number (by 0.36 animals, $3.8 \%$ ) of reared piglets. It seems to be consistent with the observations of CSAPÓ et al. (2001) who found the highest concentration of basic components in colostrum at litter population amounting to 10-12 piglets. In the opinion of the authors, milk composition is dependent on this trait and the decline $<10$ piglets or increase $>12$ animals in the litter causes decrease of concentration of nutrients.

Quality of milk is determined by chemical composition, content of nutrients and energetic value and is affected by breed, nutrition and number of lactation and its stage (MIGDAŁ 1991, TILTON et al. 1999, MIDGAŁ et al. 2000). Chemical composition of colostrum and milk of the sows in various lactation stages and, first of all, the level of dry matter, fat and protein are subjected to considerable fluctuations whereas the level of lactose which affects directly the milk yield, remains stable (MIGDAŁ et al. 2003, RENAUDEAU et al. 2003). According to REVELL et al. (1998), the content of lactose in the milk obtained at early stage of lactation i.e. between the 4th and 8th day is dependent on fatness of the sows. In "fattened « females, as compared to the »lean « ones, its content is lower (52.1 vs. $54.7 \mathrm{~g} / \mathrm{l})$. Similar tendency was stated by WALKIEWICZ et al. (1994); such relationship for colostrum and milk was not recorded in own studies. CLOWES et al. (2003) express the opinion that protein concentration in milk, during a final stage of lactation (ca. 20th day) reflects the quantity of body's protein, utilized by the sows during this period. It was the lowest in the sows who mobilized the greatest quantity of protein from their own body. It is difficult to take a position on it, when analyzing the results of own studies because with the differentiated utilization of body reserves, the sows from groups I and II produced milk with a similar chemical composition (excluding fat content), including the similar protein level. Own results may only indicate that lactation feed, as consumed by the sows, covered the production requirements connected with production of colostrum and milk. Also, in the studies on the sows, differing in fat reserves at mating, WALKIEWICZ et al. (1994) found small differences in milk protein level. The opinion of REVELL et al. (1998) stating that milk composition, excluding fat content, is rather stable and cannot be changed, including protein content, via the supply of components from internal of external sources, seems to be right.

The results of own studies and of others show that during lactation, the content of calcium, phosphorus and magnesium increases and that one of potassium and sodium becomes decreased (CSAPÓ et al. 1996, REKIEL et al. 2004). Their level is also affected by breed, feed composition and water quality (MIGDAŁ et al. 2000). Optimal supply of mineral components together with colostrum and milk determines the correct metabolic transformations in young pigs' bodies during growth and development period.

WALKIEWICZ et al. (1994) demonstrated that three from unsaturated fatty acids, i.e. C 16:1, C 18:1 and C 18:3 are dependent (in respect of quality) on backfat thickness during mating. The milk form the sows with thicker backfat $\left(P_{2}>15 \mathrm{~mm}\right)$ contained more C $16: 1$ and $C 18: 2$ acids what was compensated in the group of sows with thicker backfat $\left(P_{2}<15 \mathrm{~mm}\right)$ with the increase of $C 18: 1 \mathrm{acid}$. In own studies, such relationships were not found. On the other hand, differences in fatty acid profile between milk and colostrum 
were recorded. In final lactation stage (milk) in comparison with initial stage (colostrum), the participation of $C 14: 0, C 16: 0$ and $C 16: 1$ was significantly increased $(P \leq 0.01)$; the participation of CLA was insignificantly increased and that one of all remaining fatty acids was simultaneously decreased $(P \leq 0.01)$. The results obtained by MIGDA et al. (2000) confirm the increase of SFA during lactation, as being observed in own studies. The level of changes (milk vs. colostrum) was equal to $9.8 \%$ in group I and to $8.6 \%$ in group II what indicates utilization of the own fat tissue by the sows for milk fat production. The obtained sequence of fatty acids in fat of colostrum and milk according to their percentage in fatty acid profile is confirmed by the results of other authors (COFFEY et al. 1982, CSAPÓ et al. 1996). There are, however, also papers of other authors where the sequence of acids differs inconsiderably from the own results (MIGDAŁ 1991, MIGDA et al. 2000). In own studies, a significant decrease of the participation of acid C 20:4 in milk as compared to colostrum $(P \leq 0.01)$ was observed; it was almost by $60 \%$ in group I and more than 56\% in group II. MIGDAŁ (1991) and MIGDAŁ et al. (2000) found similar changes and CSAPÓ et al (1996) stated the contrary, i.e. increase of participation of the discussed acid in milk in relation to colostrum. The changes in fatty acid profile may be obtained by nutritional methods. When employing mixtures with the additional fat in nutrition of the sows, MIGDAŁ (1991) and TILTON et al. (1999) recorded the increase of monounsaturated fatty acids level, including $C 18: 1$ and increase of polyunsaturated fatty acids - C 18:2, C 18:3 and C 20:4.

Any effect of the condition of highly pregnant lows on basic chemical composition, content of mineral components and also, profile of the selected fatty acids and $\mathrm{pH}$ and SCC of colostrum and milk what could result from the correct, intensive feeding of suckling sow.

Colostrum and milk differed highly significantly $(P \leq 0.01)$ in respect of the examined chemical and physical traits, excluding C 18:1 and CLA content in fatty acid profile, and SCC.

\section{References}

Anonymous (1993) Polish Swine Nutrition Requirements IFiŻZ PAN. Omnitech-Press Warszawa [in Polish] Association of Official Analytical Chemists (1990) Official Methods of Analysis of the Associated Official Analytical Chemists. 15th ed, Chapter 32 Washington DC, USA

Auldist DE, Carlson D, Morrish L, Wakeford CM and King RH (2000) The influence of suckling interval on milk production of sows. J Anim Sci 78, 2026-31

Boss CH and Fredeen K (1989) Background equipment and methods for atomic emission spectrometry with induced plasma. Perkin Elmer [in Polish]

Bryłka J (1995) Experimental physical chemistry. PWN Warszawa [in Polish]

Cechova M and Tvrdon Z (2006) Relationship between backfat thickness and parameters of reproduction in the Czech Large White sows. Arch Tierz 49, 363-9

Clowes EJ, Aherne F X, Foxcroft G R and Baracos V E (2003) Selective protein loss in lactating sows is associated with reduced litter growth and ovarian function. J Anim Sci 81, 753-64

Coffey M T, Seerley R W and Mabry J W (1982) The effect of source of supplemental dietary energy on sow milk yield milk composition and litter performance. J Anim Sci 55, 1388-94

Cozler Y, David C, Beaumal V, Hulin JC, Neil M and Dourmad JY (1998) Effect of the feeding level during rearing on performance of large white gilts Part 1 Growth reproductive performance and feed intake during the first lactation. Reprod Nutr Develop 38, 363-75

Csapó J, Horn P and Csapó-Kiss Z (2001) Influence of the number of piglets born on the composition of sow's colostrum. Zb Bioteh Fak Univ Ljubl, Kmet Suppl 31, 183-9

Csapó J, Martin TG, Csapó-Kiss ZS and Hazas Z (1996) Protein Fats Vitamin and Mineral Concentrations in Porcine Colostrum and Milk from Parturition to 60 Days. Intern Dairy J 6, 881-902 
Jackson JR, Hurley WL, Easter RA, Jensen AH and Odle J (1995) Effects of induced or delayed parturition and supplemental dietary fat on colostrum and milk composition in sows. J Anim Sci 73, 1906-13

Kämmerer B, Muller S and Hühn U (1998) Reproductive and rearing performance of gilts with different side fat thickness before start of breeding. Arch Tierz 41, 387-96

Korhonen H, Marnila P, Gill HS (2000) Milk immunoglobulins and complement factors. Br J Nutr 84 Suppl 1, 75-80

Mc Namara LB, Stickland NC, Lynch PB, O'Connel MK and Lawlor PG (2008a) The influence of increasing feed intake during gestation on litter size piglet growth and within litter variation from birth to weaning. Arch Tierz $51 \mathrm{SI}, 23-4$

Mc Namara LB, Stickland NC, Lynch PB, O'Connel MK and Lawlor PG (2008b) Influence of five gestation feeding regimes for sows on lactation feed intake lactation weight loss subsequent farrowing rate and litter size. Arch Tierz $51 \mathrm{SI}, 25-6$

Migdał W (1991) Chemical composition of colostrum and milk in sows fed diets supplemented with animal fat. World Rev Anim Prod 26 4, 11-5

Migdał W, Pieszka M, Barowicz T and Pietras M (2003) Chemical composition of colostrum and milk of sows receiving CLA in feed. Medycyna Wet 59, 327-30 [in Polish]

Migdał W, Živković B, Fabjan M (2000) Chemical composition of colostrum and milk in lactation of sows.

Biotechnol Anim Husb 17 5-6, 31-8

Mullan BP and Williams IH (1989) The effect of body reserves at farrowing on the reproductive performance of first-litter sows. Anim Prod 48, 449-57

Rekiel A (2000) Lactation cycle in sows. Medycyna Wet 56, 163-7 [in Polish]

Rekiel A (2002) Effect of different drying off methods on the level of fat reserves and reproduction results in sows. Pr hab 246 Wyd SGGW, 1-99 [in Polish]

Rekiel A (2003) The choosen problems of physiology and productive of lactation of sow. Acta Scien Polon 2, 101-12 [in Polish]

Rekiel A (2006) Physiological and health aspects of lactation in sows. Post Nauk Roln 2, 23-33 [in Polish]

Rekiel A, Batorska M and Łysoniewska B (2004) The changes of the selected quality parameters of sows' milk. Zesz Nauk Przegl Hod 72 2, 33-42 [in Polish]

Renaudeau D, Noblet J and Dourmand JY (2003) Effect of ambient temperature on mammary gland metabolism in lactating sows. J Anim Sci 81, 217-31

Revell DK, Williams IH, Mullan BP, Ranford JL and Smits RJ (1998) Body composition at farrowing and nutrition during lactation affect the performance of primiparous sows: II. Milk composition milk yield and pig growth. J Anim Sci 76, 1738-43

Ruszczyc Z (1985) Animal nutrition and feed science. PWRiL Warszawa, Poland [in Polish]

SPSS (2003) User's Guide 12, 0. SPSS Inc, USA

Tilton SL, Miller PS, Lewis AJ, Reese DE and Ermer PM (1999) Addition of fat to the diets of lactating sows. I. Effects on milk production and composition and carcass composition of the litter at weaning. J Anim Sci 77, 2491-500

Wähner M, Scholz H and Kämmerer B (2001) Relationship between feed intake side fat thickness and special parameters of rearing performance of lactating sows. Arch Tierz 44, 639-48

Walkiewicz A, Wielbo E, Kamyk P and Stasiak A (1994) Effect of somatic development of gilts on the initial reproduction lactation ability and chemical composition of milk. Annal Universit Mariae CurieSkłodowska Lublin 12, 81-7 [in Polish]

Whittemore CT (1993) The Science and Practice of Pig Production. Longman, Harlow, UK

Valros A, Rundgren M, Špinka M, Saloniem H, Hultén F, Uvnäs-Moberg K, Tománek M, Krejcí P and Algers B (2004) Oxytocin prolactin and somatostatin in lactating sows associations with mobilisation of body resources and maternal behaviour. Liv Prod Sci 85, 3-13

Young MG, Tokach MD, Aherne FX, Main RG, Dritz SS, Goodband RD, Nelssen JL (2004) Comparison of three methods of feeding sows in gestation and the subsequent effects on lactation performance. J Anim Sci 82, 3058-70

Received 7 January 2009, accepted 17 August 2009.

Corresponding author:

Prof. Dr. hab. ANNA REKIEL

email: anna_rekiel@sggw.pl

Department of Animal Breeding and Husbandry, Faculty of Animal Science, SGGW-Warsaw University of Life Sciences, Ciszewskiego 8, 02-786 Warsaw, Poland 